\title{
ЯДЕРНО-ЦИТОПЛАЗМАТИЧНІ ВІДНОШЕННЯ У КАРДІОМІОЦИТАХ ТА ЕНДОТЕЛІОЦИТАХ ПЕРЕДСЕРДЬ ЛЕГЕНЕВОГО СЕРЦЯ
}

\section{ДВНЗ «Тернопільський державний медичний університет імені І. Я. Горбачевського МОз України»}

РЕЗЮМЕ. Досліджені ядерно-цитоплазматичні відношення у кардіоміоцитах та ендотеліоцитах передсердь легеневого серця. Встановлено, що співвідношення між ядром та цитоплазмою вказаних клітин пердсердь легеневого серця суттєво змінювалися, що свідчило про порушення клітинного структурного гомеостазу. Найвираженішими зміни ядерно-цитоплазматичних відношень виявлені у правому передсерді декомпенсованого легеневого серця.

КЛЮчОВІ СЛОВА: легеневе серце, передсердя, кардіоміоцити, ендотеліоцити.

Вступ. Сьогодні серцево-судинна патологія $\epsilon$ найпоширенішою, має тенденцію до зростання і найчастіше приводить до інвалідності та смертності населення у молодому працездатному віці. В останні десятиліття досягнуті значні успіхи в діагностиці, лікуванні та профілактиці уражень серця і судин, що призвело до зниження інвалідності та смертності населення від даної патології в деяких економічних регіонах, проте ці досягнення не знімають першочерговості вивчення цієї важливої медичної та соціальної проблеми [1, 2]. Сучасний морфолог завдяки постійному вдосконаленню технічних можливостей дослідження (гістохімія, імуногістохімія, гістологія, електронна, растрова мікроскопія, морфометрія тощо) отримує масу нових даних, фактів, які за допомогою традиційних методів морфологічного дослідження (опис та систематизація чисельних спостережень) оцінити складно та малоінформативно. Кількісна оцінка явищ, які спостерігають морфологи за допомогою сучасних методів морфологічного дослідження, стає все необхіднішою для аналізу отриманих результатів та обґрунтування досліджуваних закономірностей. Кількісним морфологічним аналізом об'єктивно отриманих групових особливостей структур та їх взаємозв'язків в організмі займається морфометрія, яка дозволяє більш адекватно та глибоко вивчати кількісні особливості фізіологічних та патологічних процесів і логічно інтерпретувати їх [3].

Ядерно-цитоплазматичні відношення в клітинах становлять великий інтерес для морфологів при вивченні станів їхньої життєдіяльності, метаболічної активності, рівнів компенсаторних реакцій і діагностики автологічних станів. На них в останні роки все частіше звертають увагу [4]. Необхідно зазначити, що в кардіоміоцитах та ендотеліоцитах судин легеневого серця вказані відношення вивчені недостатньо.

Мета дослідження. Вивчення особливостей змін ядерно-цитоплазматичних відношень в кардіоміоцитах та ендотеліоцитах артерій передсердь легеневого серця.
Матеріал і методи дослідження. Комплексними морфологічними методами досліджені передсердя 35 білих статевозрілих щурів-самців, які були поділені на 3 групи. 1 група нараховувала 12 інтактних практично здорових тварин, 2 - 15 щурів з компенсованим легеневим серцем, 3 - 8 дослідних тварин з декомпенсованим легеневим серцем. Останнє проявлялося ядухою, синюшністю видимих слизових оболонок, гідротораксом, гідроперикардом, асцитом, периферійними набряками, застійними явищами в органах великого кола кровообігу. Легеневе серце моделювали здійснюючи правосторонню пульмонектомію [5], яка призводила до легеневої гіпертензії, гіперфункції, гіпертрофії, розширення частин серця з переважаючим збільшенням маси та дилатацією порожнини правого шлуночка, тобто розвитку легеневого серця $[6,7]$. Збільшення маси частин серця та їх розширення виявляли за допомогою окремого зважування камер серця та планіметрії їх ендокардіальних поверхонь. Оперативні втручання проводили в умовах тіопенталового наркозу з дотриманням правил асептики та антисептики. Через 3 місяці від початку експерименту здійснювали евтаназію щурів шляхом кровопускання в умовах тіопенталового наркозу. Усі маніпуляції з дослідними тваринами проводили 3 дотриманням правил, передбачених Європейською комісією з нагляду за проведенням лабораторних та інших дослідів з використанням експериментальних тварин різних видів, а також згідно з «Науково-практичними рекомендаціями із утримання лабораторних тварин та роботи з ними».

Вирізані із передсердь шматочки фіксували в 10 \% нейтральному розчині формаліну і після відповідного проведення через етилові спирти зростаючої концентрації заливали в парафінові блоки за загальноприйнятою методикою. Мікротомні зрізи товщиною 5-7 мкм після депарафінізації фарбували гематоксиліном-еозином, за ванГізон, Вейгертом, Маллорі, толуїдиновим синім [8]. Морфометрично визначали діаметри кардіо- 
Огляди літератури, оригінальні дослідження, погляд на проблему

міоцитів (ДКМ), їх ядер (ДЯ), ядерно-цитоплазматичні відношення (ЯЦВ) у цих клітинах у лівому (ЛП) та правому (ПП) передсердях. В артеріях дрібного калібру (зовнішній діаметр 26-50 мкм) визначали висоту ендотеліоцитів (ВЕ), діаметр їх ядер (ДЯЕ), ядерно-цитоплазматичні відношення в ендотеліоцитах (ЯЦВЕ). При морфометрії дотримувалися правил та рекомендацій Г. Г. Автанділова [3]. Кількісні величини оброблені статистично. Обробка отриманих результатів виконана у відділі системних статистичних досліджень Тернопільського державного медичного університету імені І. Я. Горбачевського в програмному пакеті Statsoft STATISTIKA. Різницю між порівнювальними величинами визначали за критеріями Стьюдента та Манна-Уїтні [3].

Результати й обговорення. Отримані морфометричні показники представлені в таблиці 1. Усестороннім аналізом показаниху даній таблиці морфометричних параметрів встановлено, що у 2 та 3 групах спостережень вони істотно змінювалися. Діаметр кардіоміоцитів лівого передсердя у 2 групі тварин (компенсоване легеневе серце) статистично достовірно $(p<0,01)$ збільшився на $8,6 \%$, а при декомпенсації легеневого серця - на 16,7 \%. Діаметри ядер досліджуваних клітин при цьому істотно $(p<0,01)$ зросли на 5,0 та 9,6 \% відповідно. Нерівномірне, диспропорційне зростання цитоплазми та ядер кардіоміоцитів призводило до порушення співвідношень між їх просторовими характеристиками, що адекватно відображали ядерно-цитоплазматичні відношення у кардіоміоцитах лівого передсердя. Так, при компенсованому легеневому серці вказаний морфометричний параметр змінився всього на 4,6 \%, а при його декомпенсації- на 11,8\%.

Досліджувані морфометричні параметри у правому передсерді при правосторонній пульмон- ектомії змінювалися більшою мірою, порівняно 3 наведеними. Діаметр кардіоміоцитів правого передсердя компенсованого легеневого серця з високим ступенем достовірності $(p<0,001)$ збільшився на $28,6 \%$, а при його декомпенсації - на $41,4 \%$. Діаметри ядер кардіоміоцитів правого передсердя у змодельованих патологічних умовах відповідно статистично достовірно $(p<0,001)$ зросли на 22,8 та 26,3 \%. Суттєво змінювалися при цьому ядерно-цитоплазматичні відношення у досліджуваних структурах. Так, вказаний морфометричний параметр у контрольній групі спостережень дорівнював $(0,155 \pm 0,003)$, у правому передсерді компенсованого легеневого серця - $(0,142 \pm 0,002)$. Між наведеними морфометричними параметрами виявлена статистично достовірна $(p<0,01)$ різниця. При цьому останній показник був меншим за попередній на 8,4 \%, а у 3-й групі спостережень - на $20,0 \%$, порівняно з аналогічними контрольними показниками. Отримані наведені вище та проаналізовані результати даного дослідження свідчать, що при змодельованій патології отримані морфометричні параметри правого передсердя (діаметри кардіоміоцитів, їх ядер, ядерно-цитоплазматичні відношення в них) змінюються більшою мірою, порівняно з лівим. Наведене свідчить, що у змінених умовах гемодинаміки (пострезекційна артеріальна легенева гіпертензія) праве передсердя знаходиться у гірших умовах функціонування, порівняно з лівим.

Висота ендотеліоцитів артерій дрібного калібру лівого передсердя в компенсованому легеневому серці зросла на $2,9 \%$, а при його декомпенсації - на 3,6 \%, порівняно з контрольними показниками. Діаметри ядер ендотеліоцитів у даних експериментальних умовах відповідно збільшилися на 4,5 та 8,1\%. Ядерно-цитоплазматичні відношення

Таблиця 1. Морфометрична характеристика кардіоміоцитів та ендотеліоцитів передсердь легеневого серця $(\mathrm{M} \pm \mathrm{m})$

\begin{tabular}{|c|c|c|c|}
\hline \multirow{2}{*}{ Показник } & \multicolumn{3}{|c|}{ Група спостереження } \\
\hline & 1-a & $2-a$ & 3-я \\
\hline ДКМПП, мКм & $9,62 \pm 0,11$ & $10,45 \pm 0,12^{* * *}$ & $11,23 \pm 0,15^{* * *}$ \\
\hline ДЯЛП, мкм & $3,76 \pm 0,03$ & $3,95 \pm 0,05^{*}$ & $4,12 \pm 0,05^{* *}$ \\
\hline яЦВлП & $0,152 \pm 0,003$ & $0,145 \pm 0,002^{*}$ & $0,134 \pm 0,002 * *$ \\
\hline ДКМПП, мКм & $8,88 \pm 0,10$ & $11,42 \pm 0,12 * * *$ & $12,56 \pm 0,15^{* * *}$ \\
\hline ДЯПП, мкм & $3,50 \pm 0,03$ & $4,30 \pm 0,04 * * *$ & $4,42 \pm 0,03 * * *$ \\
\hline ЯЦВПП & $0,155 \pm 0,003$ & $0,142 \pm 0,002 * *$ & $0,124 \pm 0,002 * * *$ \\
\hline ВЕЛП, мКМ & $6,20 \pm 0,09$ & $6,36 \pm 0,12$ & $6,40 \pm 0,09$ \\
\hline ДЯЕЛП, мКМ & $3,10 \pm 0,05$ & $3,24 \pm 0,05^{*}$ & $3,35 \pm 0,04^{*}$ \\
\hline ЯЦВЕЛП & $0,256 \pm 0,003$ & $0,265 \pm 0,002 *$ & $0,280 \pm 0,003 * *$ \\
\hline ВЕПП, мКм & $6,10 \pm 0,12$ & $6,32 \pm 0,09 *$ & $6,45 \pm 0,11^{*}$ \\
\hline ДЯЕПП, мКМ & $3,07 \pm 0,06$ & $3,28 \pm 0,05^{*}$ & $3,41 \pm 0,04 * *$ \\
\hline ЯЦВЕПП & $0,254 \pm 0,003$ & $0,270 \pm 0,002 * * *$ & $0,288 \pm 0,002 * * *$ \\
\hline
\end{tabular}

Примітки: *- 
Огляди літератури, оригінальні дослідження, погляд на проблему

в ендотеліоцитах дрібних артерій лівого передсердя при цьому у 2-й групі спостережень зросли на 3,5\%, а у 3-й - на 9,4\%. У правому передсерді досліджувані морфометричні параметри змінювалися більшою мірою. Так, при компенсованому легеневому серці висота ендотеліоцитів досліджуваних судин правого передсердя статистично достовірно $(p<0,05)$ зросла на $3,6 \%$, а при його декомпенсації - на 5,9\%. Діаметри ядер ендотеліоцитів з високою достовірністю $(p<0,01)$ збільшилися відповідно на 6,8 та $11,1 \%$. Ядерно-цитоплазматичні відношення у досліджуваних експериментальних умовах у 2 групі спостережень виявилися зміненими на $6,23 \%$, а у 3 - на $13,4 \%$. Виявлене також свідчить, що досліджувані структури найвираженіших змін при змодельованій патології зазнавали у правому передсерді при декомпенсації легеневого серця. Особливу цінність при цьому представляють зміни ядерно-цитоплазматичних відношень. Цитоплазма і ядро клітини відмежовані одне від іншого подвійною ядерною мембраною, пронизаною порами. Вказані структури взаємозв'язані та тісно інтегровані і формують єдину структурно-функціональну систему $[3,4,9]$. Отже, ізольоване вивчення морфометричних параметрів тільки цитоплазми клітини або лише її ядра дозволить отримати одностороннє уявлення про ці структурні складові клітини. Дослідження ядерно-цитоплазматичних відношень дає можливість отримати більш адекватний, об'єктивний та глибокий аналіз взаємозв'язків ядра та цитоплазми клітин та їх змін в різних фізіологічних та патологічних умовах.

Відомо, що ядерно-цитоплазматичні відношення можуть змінюватися при функціональному напруженні (гіперфункції), а також при гіпофункції вказаних структур та при різних патологічних процесах у них. Деякі дослідники стверджують, що ядерно-цитоплазматичні відношення зростають при дедиференціюванні клітин, а при їх диференціюванні вони знижуються [3, 4]. Зниження вказаного морфометричного параметра по мірі дозрівання клітин та їх диференціації обумовлено в деякій мірі збільшенням цитоплазми за рахунок накопичення в ній специфічних функціонуючих ультраструктур. Наведене підтверджується також динамікою даних морфометричних параметрів при їх гіперфункції, що має місце в кардіоміоцитах при легеневому серці. Співвідношення між просторовими характеристиками ядра та цитоплазми клітини можуть змінюватися також при поділі клітин, їх рості, диплоїдії $[3,4]$. За даним морфометричним параметром можна судити про рівень та стабільність адапта- ційних процесів, що має важливе значення при діагностиці компенсації та декомпенсації легеневого серця $[10,11]$.

При світлооптичному дослідженні мікропрепаратів лівого та правого передсердь легеневого серця спостерігали виражені судинні розлади, дистрофічні та некробіотичні зміни кардіоміоци тів, ендотеліоцитів судин, стромальних структур, інфільтративні та склеротичні процеси. Виявлені патогістологічні процеси домінували у правому передсерді декомпенсованого легеневого серця. Виражені зміни співвідношень між просторовими характеристиками ядра та цитоплазми клітини деякі дослідники вважають порушенням або зривом структурного клітинного гомеостазу $[3,4,12]$. Дане судження підтверджувалося кореляцією між ступенем змін ядерно-цитоплазматичних відношень в кардіоміоцитах передсердь легеневого серця та патогістологічними змінами в ньому після правосторонньої пульмонектомії. Співвідношення між ядром та цитоплазмою в клітині (ядерно-цитоплазматичні відношення) можуть служити критерієм визначення ступеня порушення клітинного структурного гомеостазу. Чим більше змінений вказаний морфометричний параметр, тим вираженіші структурні зміни у клітинах та тканинах ураженого органа. Необхідно зазначити, що різний напрямок змін ядерно-цитоплазматичних відношень у кардіоміоцитах та ендотеліоцитах передсердь легеневого серця обумовлений неоднаковими функціональними напруженнями вказаних клітин $[3,4,9]$.

Отримані результати проведеного дослідження свідчать, що ядерно-цитоплазматичні відношення у клітинах $\epsilon$ важливими показниками, що відображають не лише зв'язки між ядром та цитоплазмою, а й дозволяють також судити про соматичний цитогенез, функціональний стан та структуру клітини.

Висновки. 1. Ядерно-цитоплазматичні відношення $\epsilon$ цінним інформативним показником функціонального стану клітин та їх структурних змін в умовах патології.

2. Найвираженіші зміни ядерно-цитоплазматичних відношень в кардіоміоцитах та ендотеліоцитах передсердь серцевого м'яза виявлені у правому передсерді декомпенсованого легеневого серця.

Перспективи подальших досліджень. Детальне усестороннє вивчення особливостей змін ядерно-цитоплазматичних відношень у кардіоміоцитах та ендотеліоцитах частин легеневого серця $\epsilon$ перспективною проблемою з метою їхнього врахування при діагностиці, корекції та профілактиці уражень серцевого м'яза. 
Огляди літератури, оригінальні дослідження, погляд на проблему

\section{ЛІТЕРАТУРА}

1. Амосова К. М. Клінічний перебіг та стан міокарда з хронічним легеневим серцем унаслідок хронічної обструктивної патології легень залежно від наявності легеневої гіпертензії / К. М. Амосова, Л. Ф. Конопльова, І. Д. Мазур // Серце і судини. - 2009. - № 2. - С. 48-52.

2. Коваленко В. М. Демографія і стан здоров'я народу України (аналітично-статистичний посібник) / В. М. Коваленко, В. М. Корнацький. - К. : ННЦ «Інститут кардіології ім. М.Д. Стражеска», 2010. - 144 с.

3. Автандилов Г. Г. Основы количественной патологической анатомии / Г. Г. Автандилов. - М. : Медицина, 2002. -240 c.

4. Гнатюк М. С. Особливості ядерно-цитоплазматичних відношень у епітеліоцитах слизової оболонки дванадцятипалої кишки / М. С. Гнатюк, Л. В. Татарчук, О. Б. Слабий // Науковий вісник Ужгородського університету. Серія "Медицина". - 2014. - вип. 1 (49). - С. 3-5.

5. Татарчук Л. В. Морфометричний аналіз ремодельованих камер серця після пульмонектомії / Л. В. Татарчук // Здобутки клінічної та експериментальної медицини. - 2011. - № 2 (15). - С. 123-126.
6. Норейко Б. В. Хроническое легочное сердце / Б. В. Норейко, С. Б. Норейко // Новости медицины и фармации. - 2011. - № 9 (364). - С. 14-17.

7. Cowie M. Survival of patients with a new diagnosis of heart failure: a population based study / M. Covie, D. Wood, A. Coats // Heart. - 2000. - Vol. 83. - P. 505-510.

8. Сорочинников А. Г. Гистологическая и микроскопическая техника / А. Г. Сорочинников, А. Е. Доросевич. - М.: Медицина, 1997. - 448 с.

9. Макаров М. А. Роль дисфункции эндотелия и ригидности артерий в патогенезе хронической обструктивной болезни легких / М. А. Макаров, С. Н. Авдеев, А. Г. Чучалин // Терапевтический архив. - 2012. - № 3. - С. 74-80.

10. Barnes P. Y. Chronic obstructive pulmonary disease molecular and cellular mechanisms / P. Y. Barnes, D. Shapiro, R. A. Pamwels // Eur. Respirat. J. - 2003. - Vol. 22. - P. 672-678.

11. Simonnean G. Clinical classification of pulmonary hypertension / J. Simonnean, N. Galie, L. Rubin // Y. Am. Cell. Cardiol. - 2004. - №12. - P. 55-125.

12. Садовников В.А. Моделирование состояния дезинтеграции сердца предельными загрузками / В. А. Садовников, А. Н. Баранов // Морфология.-1998. - Т. 113, № 3. C. 104-106.

\section{NUCLEO-CYTOPLASMATICAL RELATIONS OF CARDIOMYOCYTES AND ENDOTHELIOCYTES OF PULMONARY HEART ATRIUM}

\section{Horbachevsky Ternopil State Medical University}

๑O. B. Slabyi

SUMMARY. Nucleo-cytoplasmatical relations in the cardiomyocytes and endotheliocytes of atrium of pulmonary heart were studied. It was established that relations between nucleos and cytoplasmaes these cellulaes of atrium pulmonary heart essertially change that testify at disturbance cellular structural homeostasis. Changes of nucleocytoplasmatical relations prevail in right atrium in the decompensatory pulmonary heart.

KEY WORDS: pulmonary heart, atrium, cardiomyocytes, endotheliocytes. 